\title{
Effect of pomalidomide on relapsed/refractory multiple myeloma: a systematic review and meta-analysis
}

\author{
Runzhe Chen ${ }^{\bowtie}$, Yujie Wang, Chengxin Luan, Chong Gao, Xiaoping Zhang ${ }^{\bowtie}$, Baoan Chen ${ }^{\bowtie}$ \\ Department of Hematology and Oncology (Key Department of Jiangsu Medicine), Zhongda Hospital, Medical School, Southeast University, Nanjing, Jiangsu \\ Province, P.R. China \\ $\triangle$ Corresponding authors: Baoan Chen, Department of Hematology and Oncology, Zhongda Hospital, Medical School, Southeast University, Dingiiaqiao 87, \\ Gulou District, Nanjing 210009, Jiangsu Province, P.R. China. Tel: +86 25 83272006, Fax: +86 25 83272011. E-mail: cba8888@hotmail.com. Runzhe Chen, \\ Department of Hematology and Oncology, Zhongda Hospital, Medical School, Southeast University, Dingiiaqiao 87, Gulou District, Nanjing 210009, Jiangsu \\ Province, P.R. China. E-mail: runzhe.chen@seu.edu.cn. Xiaoping Zhang, Department of Hematology and Oncology, Zhongda Hospital, Medical School, \\ Southeast University, Dingjiaqiao 87, Gulou District, Nanjing 210009, Jiangsu Province, P.R. China. E-mail: zhangxiaopingseu@163.com \\ (C) Ivyspring International Publisher. This is an open access article distributed under the terms of the Creative Commons Attribution (CC BY-NC) license \\ (https://creativecommons.org/licenses/by-nc/4.0/). See http://ivyspring.com/terms for full terms and conditions.
}

Received: 2016.10.19; Accepted: 2017.02.01; Published: 2017.07.01

\begin{abstract}
In this work, we aim to further analyze the effect of pomalidomide for relapsed and/or refractory multiple myeloma (RRMM). A systematic literature search of PubMed, MEDLINE and EMBASE was conducted on September 20, 2016. Pooled effect size (ES) with corresponding $95 \%$ confidence intervals (Cls) were calculated using random-effects model. STATA software (version 12.0; Stata Corporation; College Station, TX, USA) was employed to do all statistical analyses. A total of 8 studies were included for analysis. The combined results demonstrated that the pooled proportion of overall response rate (ORR) was $0.35(95 \% \mathrm{Cl} 0.27$ to $0.43, P=0.000)$, and the pooled proportion of complete response rate (CRR) was 0.02 (95\% Cl 0.01 to $0.03, P=0.541)$. Pomalidomide was generally well tolerated by patients reported in the studies. Further studies would be required to conduct more prospective randomized controlled trials (RCTs) with larger samples to assess the proper place of pomalidomide as single agent or combined with other agents for RRMM.
\end{abstract}

Key words: pomalidomide, multiple myeloma, meta-analysis

\section{Introduction}

Multiple myeloma (MM) is a hematologic disorder characterized by the proliferation of malignant plasma cell clones in the bone marrow or/and extramedually sites [1]. It is the second most common hematologic malignancy and accounts for as many as $20 \%$ of deaths from hematological malignancies and $2 \%$ of deaths from all cancers $[2,3]$. $\mathrm{MM}$ is a heterogeneous disease, with its wide spectrum of aggression and treatment resistance and a diverse array of malignant cellular malfunctions, which drive individual clones [4, 5]. Although progresses have been made over the last few decades for the development of new and increasingly effective agents, the prognosis of MM still remains unfavorable and it is regarded as an incurable disease characterizing by rapid relapse and broad treatment refractoriness [6, 7]. To overcome this drug resistance, a number of therapeutic approaches have been developed in recent years [8]. The introduction of the immunomodulatory drugs (IMiDs) (eg. thalidomide and lenalidomide) and the proteasome inhibitors (eg. bortezomib and calfizomib), used either as single agent or combined with classic chemotherapy, have improved the outcome for patients with MM $[9,10]$. However, even in patients who achieve stringent complete response (sCR), the disease will inevitably relapse, highlighting the necessity for the development of novel agents in treating newly diagnosed and relapsed/refractory MM (RRMM) [1, 4, 11-16].

Pomalidomide is one of the potent IMiDs and has been tested with very encouraging results for $\mathrm{MM}$ 
patients in early investigations, especially in those who have been refractory to both lenalidomide- and bortezomib-based therapies $[17,18]$. It was approved by the Food and Drug Administration (FDA) in February 2013 and the European Medicines Agency (EMA) in August 2013 for use alone or in combination with dexamethasone for those patients with MM who have received at least two prior therapies including lenalidomide and bortezomib and have demonstrated disease progression on their last therapy [13, 17]. Several clinical trials have shown that pomalidomide was effective for patients with RRMM [19]. However, the overall response rate (ORR) of pomalidomide varies in these studies, and these published reports consisted of the clinical trials with small sample sizes which have no enough power to determine the efficacy of pomalidomide for RRMM [20]. Also, there are no complete summary of the efficacy and toxicity of pomalidomide for updated published clinical trials. Here, we performed a systematic review and a meta-analysis of clinical trials to summarize the effect of pomalidomide for the treatment of patients with RRMM.

\section{Methods}

\section{Study selection}

We performed a literature search without language restrictions using the databases of PubMed, MEDLINE and EMBASE on September 20, 2016 according to the Preferred Reporting Items for Systematic Reviews and Meta Analysis (PRISMA) guidelines [21]. The search strategy included the phase "pomalidomiade" pairing independently with "multiple myeloma" or "MM". The reference lists were screened of all of the identified studies in the field. Prospective trials (randomized controlled trials or single-armed observational trials) examining pomalidomiade as the treatment for RRMM were included. We included full texts and did not apply any restriction on age, gender or ethnicity. Retrospective studies, case reports, review articles and studies with less than 5 patients were excluded. When multiple publications reported on the same population, only the most recent study was included.

\section{Data extraction}

Data from each study were independently extracted by two reviewers using a standardized data-extraction form. Any disagreements were resolved by consensus or by consultation with a third reviewer. The following information was extracted from each study: (1) the first author's last name, (2) year of publication, (3) study design, (4) number and characteristics of subjects included, (5) mean age of subjects, (6) definition of RRMM, (7) dosage and procedure of pomalidomiade treatment, (8) response of the treatment, (9) patients' survival of the treatment and (10) effect size (95\% confidential interval (CI)). Qualities of included non-comparative cohort studies using the Newcastle-Ottawa scale [22] and randomized controlled trials (RCTs) using the Cochrane tool for assessment of bias were assessed [23].

\section{Statistical analysis}

Considering some of the inter-study variation, the random-effects model was chosen to increase power and precision of this analysis regardless of heterogeneity for the entire study. All statistical analyses were conducted by the STATA software (version 12.0; Stata Corporation; College Station, TX, USA). Test results were considered to be statistically significant at $p<0.05$. We estimated relative risk (RR) with their $95 \%$ CI using the standardized mean difference (SMD). Heterogeneity was evaluated by $\mathrm{I}^{2}$ values, and we considered significant heterogeneity to be present when the $\mathrm{I}^{2}$ statistic was $>50 \%$, and moderate heterogeneity when the $\mathrm{I}^{2}$ statistic was $>30 \%$.

\section{Results}

\section{Literature search}

A total of 398 publications were identified during the initial search. After removing of redundant duplicates, 334 studies were included and considered as potentially relevant studies. After screening the title or abstract, 107 studies were excluded for not involving MM. Of the remaining 227 records, 171 reports were further excluded. Afterwards, 56 reports were retrieved and evaluated in detail. 48 of these studies met the exclusion criteria with 43 not involving RRMM, 2 combining carfilzomib (another novel agent) with pomalidomiade, and 3 duplicate publications of included studies. Eventually, 8 complete papers met the selection criteria and were included in this meta-analysis (Figure 1).

\section{Study characteristics and qualities}

The design features and characteristics of the included studies were presented in Table 1, including 4 non-comparative studies [24-27] and 4 RCTs [28-31]. A total of 891 evaluable patients were enrolled in the included eight prospective studies. The overall quality of the four single-arm pilot studies was moderate according to Newcastle-Ottawa scale, and the overall quality of the four RCTs were adequate according to Cochrane tool for assessment of bias (Table 2). Regimens and dosage of pomalidomiade in different studies were also different (Table 3). 

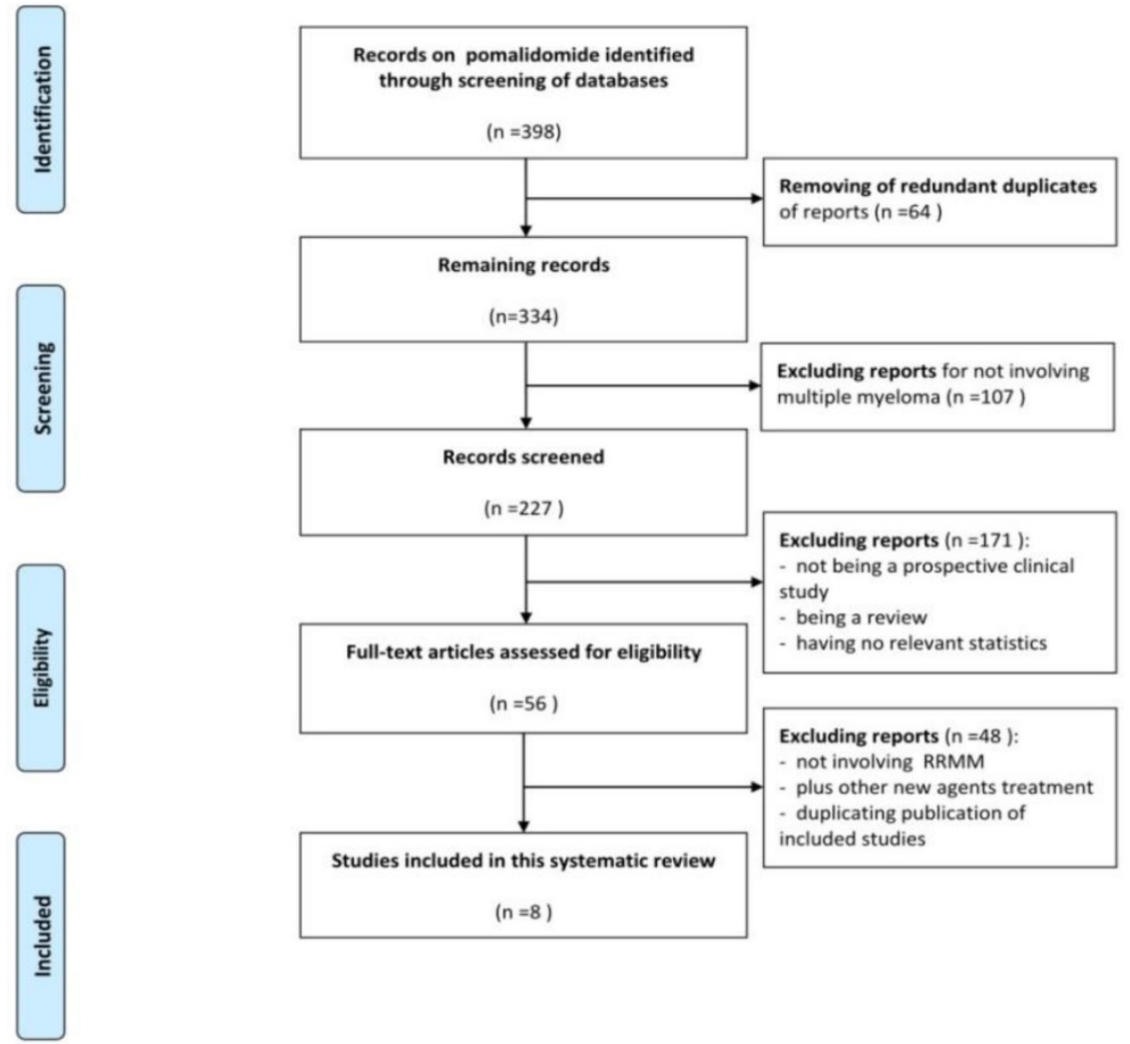

Figure 1. Data flow chart of number of studies identified and included into the meta-analysis

Table 1. Basic information and characteristics of included studies

\begin{tabular}{|c|c|c|c|c|c|c|}
\hline Study (year) & Country & Period & Design & No. of patients & $\begin{array}{l}\text { Median age, } \\
\text { range }\end{array}$ & Disease characteristics \\
\hline Lacy et al. (2009)24 & US & $\begin{array}{l}\text { November } 2007 \text { to } \\
\text { August } 2008\end{array}$ & Phase 2 & 60 & $66(35-88)$ & $\begin{array}{l}\text { At least one but no more than three prior regimens } \\
\text { (lenalidomide, thalidomide, or bortezomib) }\end{array}$ \\
\hline Lacy et al. $(2010)^{25}$ & US & $\begin{array}{l}\text { November } 2008 \text { to } \\
\text { April } 2009\end{array}$ & Phase 2 & 34 & $62(39-77)$ & $\begin{array}{l}\text { Previously treated, symptomatic, histologically } \\
\text { confirmed MM refractory to lenalidomide therapy }\end{array}$ \\
\hline \multirow[t]{2}{*}{ Lacy et al. $(2011)^{26}$} & US & $\begin{array}{l}\text { May } 2009 \text { to } \\
\text { November } 2009\end{array}$ & Phase 2 & 35 (2mg) & $63(39-77)$ & $\begin{array}{l}\text { Previously treated, symptomatic MM refractory to } \\
\text { both lenalidomide and bortezomib therapy }\end{array}$ \\
\hline & & $\begin{array}{l}\text { November } 2009 \text { to } \\
\text { April } 2010\end{array}$ & & $35(4 \mathrm{mg})$ & $61(45-77)$ & \\
\hline Leleu et al. $(2013)^{28}$ & France & $\begin{array}{l}\text { October } 2009 \text { to } \\
\text { August } 2010\end{array}$ & $\begin{array}{l}\text { Randomized } \\
\text { phase } 2\end{array}$ & $\begin{array}{l}43(\operatorname{arm} 21 / 28) \\
41(\operatorname{arm} 28 / 28)\end{array}$ & $\begin{array}{l}60(45-81) \\
60(42-83)\end{array}$ & $\begin{array}{l}\text { Relapsed MM after at least one prior regimen of } \\
\text { myeloma treatment, nonresponders to at least two } \\
\text { cycles of either the last line of lenalidomide or } \\
\text { bortezomib }\end{array}$ \\
\hline San et al. $(2013)^{29}$ & $\begin{array}{l}\text { Australia, } \\
\text { Canada, } \\
\text { Europe, } \\
\text { Russia and } \\
\text { the US }\end{array}$ & $\begin{array}{l}\text { March } 2011 \text { to Aug } \\
2012\end{array}$ & $\begin{array}{l}\text { Randomized } \\
\text { phase } 3\end{array}$ & $302^{*}$ & $64(35-84)$ & $\begin{array}{l}\text { Refractory or relapsed and refractory MM, and had } \\
\text { failed at least two previous treatments of } \\
\text { bortezomib and lenalidomide }\end{array}$ \\
\hline $\begin{array}{l}\text { Richardson et al. } \\
(2014)^{30}\end{array}$ & $\begin{array}{l}\text { US and } \\
\text { Canada }\end{array}$ & $\begin{array}{l}\text { December } 2009 \text { to } \\
\text { April 1, } 2011\end{array}$ & $\begin{array}{l}\text { Randomized } \\
\text { phase } 2\end{array}$ & $\begin{array}{l}\text { 113(POM+LoDEX) } \\
\text { 108(POM alone) }\end{array}$ & $\begin{array}{l}64(34-88) \\
61(37-88)\end{array}$ & $\begin{array}{l}\text { Aged } \geq 18 \text { years, had RRMM, and had measurable } \\
\text { M-paraprotein levels in serum or urine. All } \\
\text { patients had received } \geq 2 \text { prior antimyeloma } \\
\text { therapies, including } \geq 2 \text { cycles of lenalidomide and } \\
\geq 2 \text { cycles of bortezomib, given separately or in } \\
\text { combination }\end{array}$ \\
\hline Leleu et al. (2015) ${ }^{27}$ & France & $\begin{array}{l}\text { January } 2012 \text { to July } \\
2013\end{array}$ & Phase 2 & 50 & $59(30-80)$ & $\begin{array}{l}\text { RRMM following at least } 1 \text { prior regimen of } \\
\text { myeloma treatment. All patients had loss of } 17 \mathrm{p} \\
(46 \%) \text { and } / \text { or } \mathrm{t}(4 ; 14)(64 \%)\end{array}$ \\
\hline Baz et al. $(2016)^{31}$ & US & $\begin{array}{l}\text { December } 2011 \text { to } \\
\text { March } 2014\end{array}$ & $\begin{array}{l}\text { Randomized } \\
\text { phase } 2\end{array}$ & $\begin{array}{l}\text { 36(PomDex) } \\
\text { 34(PomCyDex) }\end{array}$ & $\begin{array}{l}64(50-78) \\
65(47-80)\end{array}$ & $\begin{array}{l}\text { RRMM received } \geq 2 \text { prior lines of therapies to } \\
\text { include a prior immunomodulatory drug, and } \\
\text { patients were required to be refractory to } \\
\text { lenalidomide }\end{array}$ \\
\hline
\end{tabular}


Table 2. The quality of included studies

\begin{tabular}{|c|c|c|c|c|c|c|}
\hline \multicolumn{7}{|l|}{ Noncomparative studies } \\
\hline Study (year) & $\begin{array}{l}\text { Representativeness of } \\
\text { study sample }\end{array}$ & $\begin{array}{l}\text { Ascertainment of } \\
\text { exposure }\end{array}$ & $\begin{array}{l}\text { Demonstration } \\
\text { outcome was not } \\
\text { present at start }\end{array}$ & $\begin{array}{l}\text { Detection bias } \\
\text { minimized }\end{array}$ & $\begin{array}{l}\text { Attribution bias } \\
\text { minimized }\end{array}$ & $\begin{array}{l}\text { Follow-up time } \\
\text { appropriate }\end{array}$ \\
\hline Lacy et al. (2009) 24 & Yes & Yes & Yes & Yes & Yes & Yes \\
\hline Lacy et al. (2010)25 & Yes & Yes & Yes & Yes & Yes & Yes \\
\hline Lacy et al. (2011) 26 & Yes & Yes & Yes & Yes & Yes & Yes \\
\hline Leleu et al. $(2015)^{27}$ & Yes & Yes & Yes & Yes & Yes & Yes \\
\hline \multicolumn{7}{|c|}{ Randomized controlled trials } \\
\hline Study & $\begin{array}{l}\text { Random sequence } \\
\text { generation }\end{array}$ & $\begin{array}{l}\text { Allocation } \\
\text { concealment }\end{array}$ & Performance bias & Detection bias & $\begin{array}{l}\text { Attribution bias } \\
\text { minimized }\end{array}$ & $\begin{array}{l}\text { Reporting bias } \\
\text { minimized }\end{array}$ \\
\hline Leleu et al. (2013) ${ }^{28}$ & Yes & Unclear & Unclear & Unclear & Yes & Unclear \\
\hline San et al. $(2013)^{29}$ & Yes & Unclear & Unclear & Unclear & Yes & Unclear \\
\hline Richardson et al. (2014) $)^{30}$ & Yes & Unclear & Unclear & Unclear & Yes & Unclear \\
\hline Baz et al. (2016) $)^{31}$ & Yes & Unclear & Unclear & Unclear & Yes & Unclear \\
\hline
\end{tabular}

Table 3. Regimen and Dosage of the treatment

\begin{tabular}{|c|c|}
\hline Study (year) & Treatment \\
\hline Lacy et al. (2009) ${ }^{24}$ & $\begin{array}{l}\text { Pomalidomide was administered orally at a dose of } 2 \mathrm{mg} \text { daily on days } 1 \text { through } 28 \text { of a } 28 \text {-day cycle. Dexamethasone } 40 \text { mg daily } \\
\text { was administered orally on days } 1,8,15 \text {, and } 22 \text { of each cycle. }\end{array}$ \\
\hline Lacy et al. (2010) 25 & $\begin{array}{l}\text { Pomalidomide was given orally at a dose of } 2 \mathrm{mg} \text { daily on days } 1-28 \text { of a } 28 \text {-day cycle. Dexamethasone was given orally at a dose of } \\
40 \mathrm{mg} \text { daily on days } 1,8,15 \text { and } 22 \text { of each cycle. }\end{array}$ \\
\hline Lacy et al. $(2011)^{26}$ & $\begin{array}{l}\text { Pomalidomide was given orally at a dose of } 2 \text { or } 4 \mathrm{mg} \text { daily on days 1-28 of a 28-day cycle. Dexamethasone was given orally at a dose } \\
\text { of } 40 \mathrm{mg} \text { daily on days } 1,8,15 \text {, and } 22 \text { of each cycle. }\end{array}$ \\
\hline Leleu et al. (2013) ${ }^{28}$ & $\begin{array}{l}\text { Pomalidomide } 4 \mathrm{mg} \text { was given orally either daily on days } 1 \text { to } 21 \text { of each } 28 \text { - day cycle }(\operatorname{arm} 21 / 28 \text { days) or continuously of each } \\
\text { 28-day cycle (arm } 28 / 28 \text { days). Dexamethasone } 40 \mathrm{mg} \text { was given orally and once weekly to all patients. }\end{array}$ \\
\hline San et al. $(2013)^{29}$ & $\begin{array}{l}\text { Patients assigned to the pomalidomide plus low-dose dexamethasone group were given } 28 \text { day cycles of pomalidomide }(4 \mathrm{mg} / \text { day } \\
\text { on days } 1-21 \text {, orally) plus low-dose dexamethasone }(40 \mathrm{mg} / \text { day on days } 1,8,15 \text {, and } 22 \text {, orally). Patients assigned to the high-dose } \\
\text { dexamethasone group were given } 28 \text { day cycles of high-dose dexamethasone }(40 \mathrm{mg} \text { / day on days } 1-4,9-12, \text { and } 17-20) \text {. } \\
\text { Dexamethasone dose was reduced to } 20 \mathrm{mg} \text { / day in all patients older than } 75 \text { years. Treatment was continued until progressive } \\
\text { disease or unacceptable toxicity occurred. }\end{array}$ \\
\hline Richardson et al. $(2014)^{30}$ & $\begin{array}{l}\text { Patients were randomized (1:1) to POM ( } 4 \mathrm{mg} / \text { day on days } 1-21 \text { of each } 28 \text {-day cycle) alone or with LoDEX ( } 40 \mathrm{mg} / \text { week). } \\
\text { Treatment continued until disease progression or unacceptable toxicity. }\end{array}$ \\
\hline Leleu et al. (2015) ${ }^{27}$ & $\begin{array}{l}\text { Pomalidomide } 4 \mathrm{mg} \text { was given orally daily on days } 1 \text { to } 21 \text { of each } 28 \text {-day cycle along with dexamethasone } 40 \mathrm{mg} \text {, which was given } \\
\text { orally to all patients on days } 1,8,15 \text {, and } 22 \text { of each cycle. The treatment was given until progression. }\end{array}$ \\
\hline Baz et al. $(2016)^{31}$ & $\begin{array}{l}\text { In the phase } 1 \text { (arm A) portion of the study, patients received pomalidomide at } 4 \text { mg orally on days } 1 \text { to } 21 \text { of a } 28 \text {-day cycle, oral } \\
\text { weekly cyclophosphamide (dose escalation } 300-500 \mathrm{mg} \text { ) on days } 1,8 \text {, and } 15 \text { (dose level } 21 \text { was cyclophosphamide } 300 \mathrm{mg} \text { orally on } \\
\text { days } 1 \text { and } 8 \text { only). Patients also received dexamethasone } 40 \mathrm{mg} \text { orally on days } 1 \text { to } 4 \text { and } 15 \text { to } 18 \text { of a } 28 \text {-day cycle for the first } 4 \\
\text { cycles and subsequently } 40 \mathrm{mg} \text { orally on days } 1,8,15 \text {, and } 22 \text {. The dose escalation used a standard " } 3+3 \text { " design. In the phase } 2 \\
\text { portion of the study, patients were randomized to either arm B (pomalidomide and low-dose dexamethasone) or arm C } \\
\text { (pomalidomide cyclophosphamide, and low-dose dexamethasone at the recommended phase } 2 \text { dose determined in arm A). Arm B } \\
\text { patients received pomalidomide at } 4 \mathrm{mg} \text { orally days } 1 \text { to } 21 \text { and dexamethasone } 40 \mathrm{mg} \text { weekly and arm C patients received } \\
\text { pomalidomide } 4 \mathrm{mg} \text { days } 1 \text { to } 21 \text {, dexamethasone } 40 \mathrm{mg} \text { weekly, and oral cyclophosphamide } 400 \mathrm{mg} \text { orally on days } 1,8 \text {, and } 15 \text { of a } \\
\text { 28-day cycle. Patients who experienced progressive disease in arm B were allowed to crossover to arm D at the discretion of the } \\
\text { treating physician, in which case oral weekly cyclophosphamide ( } 400 \text { mg orally on days } 1,8 \text {, and } 15 \text { ) was added to their tolerated } \\
\text { dose of pomalidomide and dexamethasone. }\end{array}$ \\
\hline
\end{tabular}

\section{Response rate of pomalidomide treatment}

Because there were three studies using different regimens of pomalidomide, we divided them into two parts when analyzed [26, 30, 31]. Efficacy of the treatment was summarized in Table 4, including ORR, complete response (CR), very good partial response (VGPR), partial response (PR), median time-to-response (TOR), median overall survival (OS), median progression-free survival (PFS) and median duration of response (DOR). Data on the ORR (the rate of CR plus VGPR and PR) were extracted from the eight studies selected (891 patients). The random-effects model was chosen, and a high heterogeneity between studies $\left(I^{2}=83.4 \%\right)$ was observed. The pooled proportion of ORR was 0.35 (95\% CI 0.27 to $0.43, P=0.000$ ) (Figure 2). Data on the complete response rate (CRR) were also extracted, and no heterogeneity existed $\left(I^{2}=0.0 \%\right)$. The pooled proportion of CRR was 0.02 (95\% CI 0.01 to 0.03 , $P=0.541$ ) (Figure 3).

\section{Potential side effects of pomalidomide treatment}

The safety of pomalidomide was deemed good and no long-term complications were reported. In our included studies, common hematologic toxicities of the patients in different studies consisted of anemia, neutropenia and thrombocytopenia; nonhematologic toxicities included fatigue, dyspnea, bone pain, renal failure and pneumonia (Table 5). Mortality of patients seldom occurred in the studies and no deaths were attributed to pomalidomide. 
Table 4. Efficacy of the treatment

\begin{tabular}{|c|c|c|c|c|c|c|c|c|c|}
\hline Study (year) & Total no. & $\mathrm{ORR}(\geq \mathrm{PR})$ & CR & VGPR & PR & $\begin{array}{l}\text { Median TOR, } \\
\text { months }\end{array}$ & $\begin{array}{l}\text { Median OS, } \\
\text { months }\end{array}$ & $\begin{array}{l}\text { Median PFS, } \\
\text { months }\end{array}$ & $\begin{array}{l}\text { Median DOR, } \\
\text { months }\end{array}$ \\
\hline Lacy et al. (2009) 24 & 60 & $38(63 \%)$ & $3(5 \%)$ & $17(28 \%)$ & $18(30 \%)$ & - & Not reached & 11.6 & Not reached \\
\hline Lacy et al. (2010) 25 & 34 & $11(32 \%)$ & 0 & $3(9 \%)$ & $8(24 \%)$ & 2 & 13.9 & 4.8 & 9.1 \\
\hline \multirow[t]{2}{*}{ Lacy et al. $(2011)^{26}$} & $35(2 \mathrm{mg})$ & $9(26 \%)$ & 0 & $5(14 \%)$ & $4(11 \%)$ & 1 & Not reached & 6.5 & Not reached \\
\hline & $35(4 \mathrm{mg})$ & $10(29 \%)$ & $1(3 \%)$ & $3(9 \%)$ & $6(17 \%)$ & 1.7 & Not reached & 3.2 & 3.9 \\
\hline Leleu et al. (2013) ${ }^{28}$ & 84 & $29(35 \%)$ & $3(4 \%)$ & $2(2 \%)$ & $24(29 \%)$ & 5.4 & 14.9 & 4. & 7.3 \\
\hline San et al. $(2013)^{29}$ & 302 & $95(31 \%)$ & $3(1 \%)$ & $14(5 \%)$ & $78(26 \%)$ & - & 13.1 & 4.0 & 7.5 \\
\hline \multirow[t]{2}{*}{ Richardson et al. (2014) ${ }^{30}$} & 113(POM+LoDEX) & $37(33 \%)$ & $3(3 \%)$ & 0 & $34(30 \%)$ & 1.9 & 16.5 & 4.2 & 8.3 \\
\hline & 108(POM alone) & $19(18 \%)$ & $2(2 \%)$ & 0 & $17(16 \%)$ & 4.3 & 13.6 & 2.7 & 10.7 \\
\hline Leleu et al. (2015) ${ }^{27}$ & 50 & $11(22 \%)$ & $3(6 \%)$ & 0 & $8(16 \%)$ & 4.1 & 12 & 2.8 & 5.5 \\
\hline \multirow[t]{2}{*}{ Baz et al. $(2016)^{31}$} & 36(PomDex) & $14(39 \%)$ & $1(3 \%)$ & $4(11 \%)$ & $9(25 \%)$ & - & 16.8 & 4.4 & - \\
\hline & 34(PomCyDex) & $22(65 \%)$ & $1(3 \%)$ & $3(9 \%)$ & $18(53 \%)$ & - & Not reached & 9.5 & - \\
\hline
\end{tabular}

CR, complete response; DOR, duration of response; ORR, overall response rate; OS, overall survival; PFS, progression-free survival; PR, partial response; POM, pomalidomide; PomCyDex , pomalidomide, dexamethasone and cyclophosphamide; PomDex, pomalidomide and low-dose dexamethasone; POM+LoDEX, pomalidomide plus low-dose dexamethasone; TOR, time to response; VGPR, very good partial response

Study

ID

ES $(95 \% \mathrm{Cl})$

Lacy et al. (2009)

Lacy et al. (2010)

Lacy et al. (2011)1

Lacy et al. (2011)2

Leleu et al. (2013)

San et al. (2013)

Richardson et al. (2014)1

Richardson et al. (2014)2

Leleu et al. (2015)

Baz et al. (2016)1

Baz et al. (2016)2

Overall $(\mathrm{I}$-squared $=83.4 \%, p=0.000)$

NOTE: Weights are from random effects analysis

$-81$

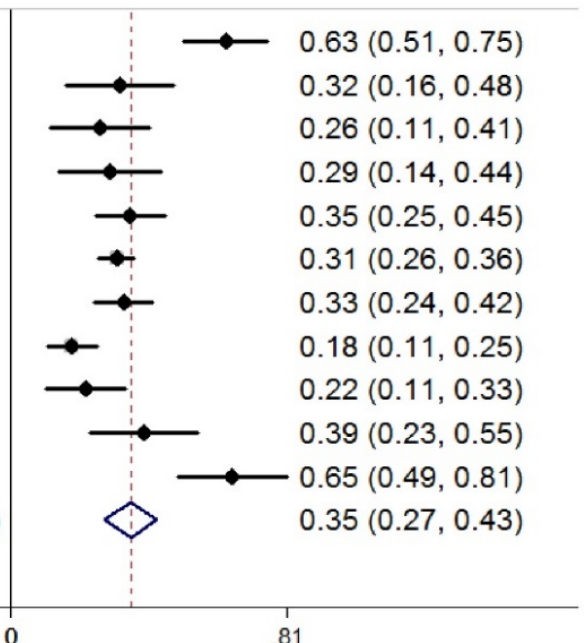

Figure 2. Overall response of pomalidomide treatment in patients with RRMM. (RRMM, relapsed/refractory multiple myeloma; ES, effect size)

Study

ID

ES $(95 \% \mathrm{Cl})$

Lacy et al. (2009)

Lacy et al. (2011)2

Leleu et al. (2013)

San et al. (2013)

Richardson et al. (2014)1

Richardson et al. (2014)2

Leleu et al. (2015)

Baz et al. (2016)1

Baz et al. (2016)2

Lacy et al. (2010)

Lacy et al. (2011)1

Overall $(I$-squared $=0.0 \%, p=0.541$ )

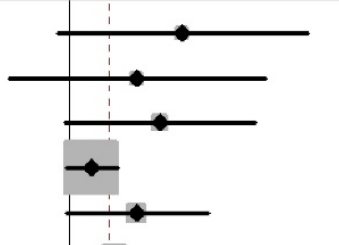

$0.05(-0.01,0.11)$

$0.03(-0.03,0.09)$

$0.04(-0.00,0.08)$

$0.01(-0.00,0.02)$

$0.03(-0.00,0.06)$

$0.02(-0.01,0.05)$

NOTE: Weights are from random effects analysis

$-.126$

0

Figure 3. Complete response of pomalidomide treatment in patients with RRMM. (RRMM, relapsed/refractory multiple myeloma; ES, effect size) 
Table 5. Adverse effects of pomalidomide treatment

\begin{tabular}{|c|c|}
\hline Study (year) & Treatment \\
\hline Lacy et al. (2009) ${ }^{24}$ & $\begin{array}{l}\text { Toxicity consisted primarily of myelosuppression. Grade } 3 \text { or } 4 \text { hematologic toxicity occurred in } 23 \text { patients }(38 \%) \text { and consisted of anemia } \\
(5 \%) \text {, thrombocytopenia ( } 3 \%) \text {, and neutropenia (32\%). The most common grade } 3 \text { or } 4 \text { nonhematologic toxicities consisted of fatigue (17\%) } \\
\text { and pneumonia ( } 8 \%) \text {. }\end{array}$ \\
\hline Lacy et al. (2010)25 & $\begin{array}{l}\text { Toxicity consisted primarily of myelosuppression. Grade } 3 \text { or } 4 \text { hematologic toxicity occurred in } 13 \text { patients }(38 \%) \text { and consisted of anemia } \\
(12 \%) \text {, thrombocytopenia }(9 \%) \text { and neutropenia }(29 \%) \text {. The most common grade } 3 / 4 \text { non-hematologic toxicity was fatigue }(9 \%) \text {. }\end{array}$ \\
\hline Lacy et al. $(2011)^{26}$ & $\begin{array}{l}\text { Toxicity consisted primarily of myelosuppression. Grade } 3 \text { or } 4 \text { hematologic toxicity regardless of attribution occurred in } 83 \% \text { ( } 2 \text {-mg cohort) } \\
\text { and } 80 \% \text { (4-mg cohort) and at least possibly attributed to the regimen occurred in } 71 \% \text { ( } 2 \text {-mg cohort) and } 74 \% \text { ( } 4 \text {-mg cohort). Grade } 3 \text { or } 4 \\
\text { neutropenia (regardless of attribution) was seen in } 51 \% \text { (2-mg cohort) and } 66 \% \text { (4-mg cohort). Grade } 3 \text { or } 4 \text { nonhematologic toxicity } \\
\text { regardless of attribution occurred in } 69 \% \text { (2-mg cohort) and } 54 \% \text { (4-mg cohort) and at least possibly attributed to the regimen was seen in } \\
26 \% \text { ( } 2 \text {-mg cohort) and } 26 \% \text { (4-mg cohort). The most common nonhematologic toxicity was fatigue ( } 2 \text {-mg cohort: } 88 \% ; 4 \text {-mg cohort: } 91 \%) \\
\text { with grade } 3 / 4 \text { fatigue occurring in } 9 \% \text { of patients in both cohorts. }\end{array}$ \\
\hline Leleu et al. (2013) ${ }^{28}$ & $\begin{array}{l}\text { Grade } 3 \text { and } 4 \text { AEs that occurred in }>10 \% \text { of cases were neutropenia in } 62 \% \text {, anemia in } 36 \% \text {, thrombocytopenia in } 27 \% \text {, pneumonia in } 13 \% \text {, } \\
\text { bone pain in } 11 \% \text {, renal failure in } 11 \% \text {, and dyspnea in } 12 \% \text {. }\end{array}$ \\
\hline San et al. (2013) & $\begin{array}{l}\text { The most common grade } 3-4 \text { hematological AEs in the POM+LoDEX and HiDEX groups were neutropenia (143 [ } 48 \%] \text { of } 300 \text { vs } 24 \text { [16\%] of } \\
150 \text {, respectively), anemia }(99[33 \%] \text { vs } 55[37 \%] \text {, respectively), and thrombocytopenia ( } 67 \text { [22\%] vs } 39[26 \%] \text {, respectively). Grade } 3-4 \\
\text { non-hematological adverse events in the POM+LoDEX and HiDEX groups included pneumonia (38 [13\%] vs } 12[8 \%] \text {, respectively), bone } \\
\text { pain ( } 21[7 \%] \text { vs seven }[5 \%] \text {, respectively), and fatigue (16 [5\%] vs nine [6\%], respectively). }\end{array}$ \\
\hline $\begin{array}{l}\text { Richardson et al. } \\
(2014)^{30}\end{array}$ & $\begin{array}{l}\text { The most common grade } 3-4 \text { AE was neutropenia, which occurred in } 41 \% \text { of patients treated with POM+LoDEX and } 48 \% \text { of patients treated } \\
\text { with POM alone. The incidence of grade } 3-4 \text { febrile neutropenia was low in the POM+LoDEX and POM alone groups ( } 3 \% \text { and } 5 \% \text {, } \\
\text { respectively). The most common grade } 3-4 \text { nonhematologic AE was pneumonia ( } 22 \% \text { with POM+LoDEX and } 15 \% \text { with POM alone). In the } \\
\text { POM1LoDEX group, } 27 \% \text { of the cases of any grade pneumonia were also associated with dyspnea (any grade). }\end{array}$ \\
\hline Leleu et al. (2015) ${ }^{27}$ & $\begin{array}{l}\text { The toxicity profile of the Pom-Dex combination consisted primarily of myelosuppression, as previously reported, and appeared } \\
\text { manageable in these fragile RRMM patients. A total of } 49 \text { patients }(98 \%) \text { experienced an AE, of which } 44 \text { ( } 88 \%) \text { were treatment related. The } \\
\text { incidence rate of grade } 3 \text { and } 4 \text { AEs was } 45(90 \%) \text {, including hematologic AEs, and } 32(64 \%) \text { experienced a serious adverse event (SAE). }\end{array}$ \\
\hline Baz et al. (2016) ${ }^{31}$ & $\begin{array}{l}\text { Grade } 3 \text { and } 4 \text { anemia, neutropenia, and thrombocytopenia were noted in } 11 \%, 31 \% \text {, and } 6 \% \text { of arm B patients vs in } 24 \%, 52 \% \text {, and } 15 \% \text { of } \\
\text { arm C patients, respectively. Gastrointestinal toxicity including nausea, vomiting, and diarrhea was also similar in the } 2 \text { treatment arms. }\end{array}$ \\
\hline
\end{tabular}

\section{Discussion}

Pomalidomide is a second generation IMiDs and has demonstrated effective even in MM patients who were refractory to lenalidomide and bortezomib [32]. The reason why it was approved by FDA is that in several clinical trials it shows sustained and significant effects and great antitumor activity in RRMM [29, 33-35]. In this meta-analysis, we summarized and evaluated the efficacy of pomalidomide in the treatment of RRMM. We identified eight studies, including four RCTs and four single-armed prospective studies with 891 patients. The qualities of the eight studies were adequate. The random-effects model was chosen, and a high heterogeneity between studies was observed.

Current treatment standards of RRMM include salvage chemotherapy, salvage autologous stem cell transplantation (auto-SCT), allogeneic stem cell transplantation (allo-SCT) and post-transplant consolidation/maintenance therapy [36-38]. For those patients who received salvage chemotherapy, thalidomide, lenalidomide and bortezomib could be the treatments of choice. However, if the patients are still refractory to bortezomib or lenalidomide, it seemed it would be no good options for them. As a novel agent for RRMM, pomalidomide showed to have encouraging result for RRMM, as our analysis showed that the pooled proportion of ORR was 0.35 and CRR was 0.02 after pomalidomide therapy. This might better guide us the further use this agent. Of noted, ORR of pomalidomide as single agent was only
$18 \%$ in the study conducted by Richardson et al [30], but ORR became $33 \%$ once combining pomalidomide with dexamethasone for RRMM patients. The effect of combination of pomalidomide with dexamethasone or cyclophosphamide were better than that of single agent was also seen in other studies included, but the severe toxicities resulted from combination treatment also needs our attention. It seems that the higher dosage of pomalidomide $(4 \mathrm{mg})$ is not correlated with better ORR and survival of RRMM patients compared to that of lower dosage ( $2 \mathrm{mg}$ ) in our analysis, but we need further confirmation in case that it is the coincidence because only a small number of patients were included in the analysis. Given these findings, we may conclude that combination treatment would be better than that of the single agent therapy for RRMM.

Several limitations associated with this meta-analysis were recognized. Firstly, most of the studies we included had different treatment regimens and dosage, and it is hard to be uniformed. Also, the precision of pooled ES can be affected by the small sample size of some studies; therefore, we chose the random-effects model for the entire study to increase power and precision regardless of heterogeneity. Moreover, the effect of pomalidomide might vary by different ethnicities around the world, and it is difficult to summarize them.

Further studies would be required to address the more concrete mechanisms of pomalidomide for MM. Though the pooled ORR and CR in our analysis demonstrated some advantages of pomalidomide for 
those patients even refractory to bortezomib and lenalidomide, the sample size is small, so the conduction of more prospective RCTs with larger samples to assess the proper place of pomalidomide for single agent or combined with other agents in RRMM is necessary, and toxicities of pomalidomide should also be carefully monitored. What's more, whether pomalidomide can be extended to newly diagnosed or more advanced MM [39-41] or other hematological malignancies require further studying [42].

\section{Author Contributions}

$\mathrm{RC}$ and $\mathrm{BC}$ had the idea and designed this meta-analysis. RC and CL identified reports of trials and extracted data. XZ, YW and CG provided statistical advice and RC did all statistical analyses. $\mathrm{RC}, \mathrm{CL}, \mathrm{YW}$ and $\mathrm{BC}$ checked for statistical inconsistency and interpreted data. RC drafted the report and all other authors critically reviewed and approved final article. BC is guarantor of this article.

\section{Competing Interests}

The authors have declared that no competing interests exist.

\section{References}

1. Sonneveld P, Broijl A. Treatment of relapsed and refractory multiple myeloma. Haematologica. 2016; 101: 396-406.

2. San Miguel JF. Introduction to a series of reviews on multiple myeloma. Blood. 2015; 125: 3039-3040

3. Naymagon L, Abdul-Hay M. Novel agents in the treatment of multiple myeloma: a review about the future. J Hematol Oncol. 2016; 9: 52.

4. Lonial S, Durie B, Palumbo A, San-Miguel J. Monoclonal antibodies in the treatment of multiple myeloma: current status and future perspectives. Leukemia. 2016; 30: 526-535.

5. Driscoll JJ. Expression of E3 Ubiquitin Ligases in Multiple Myeloma Patients after Treatment with the Proteasome Inhibitor Bortezomib. Cancer Transl Med. 2015; 1: 153-157.

6. Laubach J, Garderet L, Mahindra A, Gahrton G, Caers J, Sezer O, et al. Management of relapsed multiple myeloma: recommendations of the International Myeloma Working Group. Leukemia. 2016; 30: 1005-1017.

7. Rajkumar SV. Myeloma today: Disease definitions and treatment advances. Am J Hematol. 2016; 91: 90-100.

8. Mimura N, Hideshima T, Anderson KC. Novel therapeutic strategies for multiple myeloma. Exp Hematol. 2015; 43: 732-741.

9. Dai $\mathrm{C}$, Chen $\mathrm{D}$, Jiang $\mathrm{Y}$. Histone $\mathrm{H} 2 \mathrm{~A}$ and $\mathrm{H} 2 \mathrm{~B}$ Deubiquitinase in Developmental Disease and Cancer. Cancer Transl Med. 2015; 1: 170-175.

10. Neri P, Bahlis NJ, Lonial S. New Strategies in Multiple Myeloma: Immunotherapy as a Novel Approach to Treat Patients with Multiple Myeloma. Clin Cancer Res. 2016; 22(24): 5959-5965.

11. Terpos E, Kanellias N, Christoulas D, Kastritis E, Dimopoulos MA. Pomalidomide: a novel drug to treat relapsed and refractory multiple myeloma. Onco Targets Ther. 2013; 6: 531-538.

12. Moreau P, Richardson PG, Cavo M, Orlowski RZ, San Miguel JF, Palumbo A, et al. Proteasome inhibitors in multiple myeloma: 10 years later. Blood. 2012; 120: 947-959.

13. Fouquet G, Bories C, Guidez S, Renaud L, Herbaux C, Javed S, et al. Pomalidomide for multiple myeloma. Expert Rev Hematol. 2014; 7: 719-731.

14. Chen R, Chen B, Zhang X, Gao C. Efficacy of carfilzomib in the treatment of relapsed and (or) refractory multiple myeloma: a meta-analysis of data from clinical trials. Discov Med. 2016; 22: 189-199.

15. Fall DJ, Stessman H, Patel SS, Sachs Z, Van Ness BG, Baughn LB, et al. Utilization of translational bioinformatics to identify novel biomarkers of bortezomib resistance in multiple myeloma. J Cancer. 2014; 5: 720-727.

16. Chen R, Chen B, Ge Z. Efficacy of Carfilzomib in the Treatment of Relapsed and (or) Refractory Multiple myeloma: a Meta Analysis of Individual Patient Data from Clinical Trials. Blood. 2016; 128: 5675.
17. Dimopoulos MA, Leleu X, Palumbo A, Moreau P, Delforge M, Cavo M, et al. Expert panel consensus statement on the optimal use of pomalidomide in relapsed and refractory multiple myeloma. Leukemia. 2014; 28: 1573-1585.

18. Laubach JP, Voorhees PM, Hassoun H, Jakubowiak A, Lonial S, Richardson PG. Current strategies for treatment of relapsed/refractory multiple myeloma. Expert Rev Hematol. 2014; 7: 97-111.

19. Zou $\mathrm{Y}, \mathrm{Ma} \mathrm{X}, \mathrm{Yu} \mathrm{H}, \mathrm{Hu} \mathrm{C}$, Fan L, Ran X. Carfilzomib/pomalidomide single-agent or in combination with other agents for the management of relapsed/refractory multiple myeloma : a meta-analysis of 37 trials. Oncotarget. 2016 Jul 21. doi: 10.18632/oncotarget.10768. [Epub ahead of print]

20. Sheng Z, Liu G. Pooled analysis of the reports of pomalidomide after failure of lenalidomide and (or) bortezomib for multiple myeloma. Hematol Oncol. 2016; 34: 102-107.

21. Moher D, Liberati A, Tetzlaff J, Altman DG. Preferred reporting items for systematic reviews and meta-analyses: the PRISMA statement. Int J Surg. 2010; 8: 336-341.

22. Tang PL, Wang HH, Chou FH. A Systematic Review and Meta-Analysis of Demoralization and Depression in Patients With Cancer. Psychosomatics. 2015; 56: 634-643.

23. Higgins JP AD, Sterne JA. Chapter 8: Assessing risk of bias in included studies. In: Higgins JPT GS, ed. Cochrane Handbook for Systematic Reviews of Interventions Version 5.1.0. The Cochrane Collaboration 2011.

24. Lacy MQ, Hayman SR, Gertz MA, Dispenzieri A, Buadi F, Kumar S, et al. Pomalidomide (CC4047) plus low-dose dexamethasone as therapy for relapsed multiple myeloma. J Clin Oncol. 2009; 27: 5008-5014.

25. Lacy MQ, Hayman SR, Gertz MA, Short KD, Dispenzieri A, Kumar S, et al. Pomalidomide (CC4047) plus low dose dexamethasone (Pom/dex) is active and well tolerated in lenalidomide refractory multiple myeloma (MM). Leukemia. 2010; 24: 1934-1939.

26. Lacy MQ, Allred JB, Gertz MA, Hayman SR, Short KD, Buadi F, et al. Pomalidomide plus low-dose dexamethasone in myeloma refractory to both bortezomib and lenalidomide: comparison of 2 dosing strategies in dual-refractory disease. Blood. 2011; 118: 2970-2975.

27. Leleu X, Karlin L, Macro M, Hulin C, Garderet L, Roussel M, et al. Pomalidomide plus low-dose dexamethasone in multiple myeloma with deletion 17p and/or translocation (4;14): IFM 2010-02 trial results. Blood. 2015; 125: 1411-1417.

28. Leleu X, Attal M, Arnulf B, Moreau P, Traulle C, Marit G, et al. Pomalidomide plus low-dose dexamethasone is active and well tolerated in bortezomib and lenalidomide-refractory multiple myeloma: Intergroupe Francophone du Myelome 2009-02. Blood. 2013; 121: 1968-1975.

29. San Miguel J, Weisel K, Moreau P, Lacy M, Song K, Delforge M, et al. Pomalidomide plus low-dose dexamethasone versus high-dose dexamethasone alone for patients with relapsed and refractory multiple myeloma (MM-003): a randomised, open-label, phase 3 trial. Lancet Oncol. 2013; 14: 1055-1066.

30. Richardson PG, Siegel DS, Vij R, Hofmeister CC, Baz R, Jagannath S, et al. Pomalidomide alone or in combination with low-dose dexamethasone in relapsed and refractory multiple myeloma: a randomized phase 2 study. Blood. 2014; 123: 1826-1832.

31. Baz RC, Martin TG, 3rd, Lin HY, Zhao X, Shain KH, Cho HJ, et al. Randomized multicenter phase 2 study of pomalidomide, cyclophosphamide, and dexamethasone in relapsed refractory myeloma. Blood. 2016; 127: 2561-2568.

32. Fouquet G, Pegourie B, Macro M, Petillon MO, Karlin L, Caillot D, et al. Safe and prolonged survival with long-term exposure to pomalidomide in relapsed/refractory myeloma. Ann Oncol. 2016; 27: 902-907.

33. Usmani SZ, Zhang Q, Stratton K, Qu P, Yaccoby S, Hansen E, et al. Phase II study of pomalidomide in high-risk relapsed and refractory multiple myeloma. Leukemia. 2014; 28: 2413-2415.

34. Larocca A, Montefusco V, Bringhen S, Rossi D, Crippa C, Mina R, et al. Pomalidomide, cyclophosphamide, and prednisone for relapsed/refractory multiple myeloma: a multicenter phase $1 / 2$ open-label study. Blood. 2013; 122: 2799-2806.

35. San Miguel JF, Weisel KC, Song KW, Delforge M, Karlin L, Goldschmidt H, et al. Impact of prior treatment and depth of response on survival in MM-003, a randomized phase 3 study comparing pomalidomide plus low-dose dexamethasone versus high-dose dexamethasone in relapsed/refractory multiple myeloma. Haematologica. 2015; 100: 1334-1339.

36. Cornell RF, Kassim AA. Evolving paradigms in the treatment of relapsed/refractory multiple myeloma: increased options and increased complexity. Bone marrow transplantation. 2016; 51: 479-491.

37. Laubach I, Garderet L, Mahindra A, Gahrton G, Caers I, Sezer O, et al. Management of relapsed multiple myeloma: recommendations of the International Myeloma Working Group. Leukemia. 2015; 30: 1005-1017.

38. Moreau P, Touzeau C. Multiple myeloma: from front-line to relapsed therapies. Am Soc Clin Oncol Educ Book. 2015: e504-511.

39. Sonneveld P, Asselbergs E, Zweegman S, van der Holt B, Kersten MJ, Vellenga E, et al. Phase 2 study of carfilzomib, thalidomide, and dexamethasone as induction/consolidation therapy for newly diagnosed multiple myeloma. Blood. 2015; 125: 449-456.

40. Mikhael JR, Reeder CB, Libby EN, Costa LJ, Bergsagel PL, Buadi F, et al. Phase $\mathrm{Ib} / \mathrm{II}$ trial of CYKLONE (cyclophosphamide, carfilzomib, thalidomide and dexamethasone) for newly diagnosed myeloma. Br J Haematol. 2015; 169: 219-227. 
41. Bringhen S, Petrucci MT, Larocca A, Conticello C, Rossi D, Magarotto V, et al. Carfilzomib, cyclophosphamide, and dexamethasone in patients with newly diagnosed multiple myeloma: a multicenter, phase 2 study. Blood. 2014; 124: 63-69.

42. Treon SP, Tripsas CK, Meid K, Kanan S, Sheehy P, Chuma S, et al. Carfilzomib, rituximab, and dexamethasone (CaRD) treatment offers a neuropathy-sparing approach for treating Waldenstrom's macroglobulinemia. Blood. 2014; 124: 503-510. 